\title{
PENGARUH PENERAPAN ONLINE SINGLE SUBMISSION (OSS) TERHADAP PERILAKU BIROKRASI DAN PELAKU USAHA SERTA DAMPAKNYA BAGI PERCEPATAN INVESTASI DI KABUPATEN BANGKA SELATAN PROVINSI KEPULAUAN BANGKA BELITUNG
}

\author{
M. Faisal Orywika ${ }^{*}$; Sampara Lukman; Layla Kurniawati \\ Pascasarjana Institut Pemerintahan Dalam Negeri Jakarta \\ *)email : mforywika@gmail.com
}

Paper Accepted: 23 September 2021 Paper Reviewed: 05-11 Oktober 2021 Paper Edited: 12-18 Oktober 2021 Paper Approved: 19 Oktober 2021

\begin{abstract}
ABSTRAK
Penerapan Online Single Submission (OSS) atau sistem perizinan berusaha terintegrasi secara elektronik merupakan tujuan yang menjadi pokok dari pelaksanaan kebijakan yang ada di Kabupaten Bangka Selatan. Penelitian ini bertujuan untuk menganalisis pengaruh OSS/Sistem Perizinan Berusaha Berbasis Elektronik (Y) terhadap perilaku birokasi (X1), Pelaku Usaha (X2) serta dampaknya pada Percepatan Investasi (Z) di Kabupaten Bangka Selatan Provinsi Kepulauan Bangka Belitung, melalui tahapan-tahapan uji statistik yang merupakan rangkaian dari penelitian ilmiah ini. Metode yang digunakan dalam penelitian ini adalah metode kuantitatif. Penelitian ini memberikan kesimpulan bahwa Online Single Submission (OSS) atau Sistem Perizinan Berusaha Terintegrasi Secara Elektronik dipengaruhi oleh perilaku birokrasi (X1), pelaku usaha $\left(\mathrm{X}_{2}\right)$ dan percepatan investasi secara berurutan sebesar 1,53\%,0,01\%, dan 17,64\%. Sementara jika ketiga variable tersebut dikombinasikan secara simultan maka akan mempengaruhi OSS sebesar $26,2 \%$.
\end{abstract}

Kata Kunci : Online Single Submission (OSS); Pengaruh Penerapan OSS, Perilaku Birokrasi, Pelaku Usaha, Percepatan Investasi dan Kabupaten Bangka Selatan.

\section{PENDAHULUAN}

Dalam penyelenggaraan $\begin{gathered}\text { pelayanan } \\ \text { pemerintah }\end{gathered}$
publik, maratur memberikan
bertanggungjawab untuk manakat
pelayanan yang terbaik kepada masyarakat
dalam rangka menciptakan kesejahteraan

masyarakat. Apabila pelayanan yang diberikan secara baik dan mampu memenuhi kebutuhan masyarakat, maka masyarakat akan merasa puas dengan apa yang diberikan sehingga masyarakat dapat menilai bahwa pelayanan yang diterimanya juga berkualitas. Karena pelayanan yang 
berkualitas mencerminkan pula kualitas pemerintahan itu sendiri.

Untuk menciptakan pelayanan perizinan yang lebih baik dan berkualitas, maka ditetapkan Peraturan Menteri Dalam Negeri Nomor 138 Tahun 2017 tentang Penyelenggaraan Pelayanan Terpadu Satu Pintu Daerah yang merupakan landasan untuk menerapkan prinsip-prinsip pelayanan dalam memenuhi kebutuhan dan kepuasan penerima pelayanan perizinan pada masing-masing daerah kabupaten/kota.

Untuk menanggulangi lemahnya pelayanan aparatur pemerintah yang menyebabkan tidak optimalnya fungsi pelayanan yang diberikan kepada masyarakat adalah dengan mengalihkan aspek-aspek dan fungsi-fungsi pemerintahan konvensional melalui penggunaan teknologi baru. Teknologi informasi memiliki peranan penting dalam mewujudkan perubahan cara kerja yang memudahkan manusia untuk menyelesaikan pekerjaannya untuk memproses dan mengirimkan informasi dalam bentuk elektronik (Lucas, 2000).

Salah satu usaha adalah dengan memanfaatkan teknologi informasi kedalam bentuk pelayanan perizinan yang terpadu (one stop service) yang sering disebut Pelayanan Terpadu Satu Pintu. Pelayanan prima dengan memanfaatkan teknologi informasi merupakan salah satu syarat terselenggaranya pemerintahan yang baik (good governance) dan pemerintahan yang bersih (clean government). Online Single Submission (OSS)/ Sistem Perizinan Berusaha Terintegrasi Secara Elektronik adalah sistem perizinan berusaha yang terintegrasi secara elektronik dengan seluruh kementerian/ lembaga (K/L) hingga pemerintah daerah.

Kebijakan ini diambil pemerintah sebagai upaya untuk meningkatkan perekonomian nasional melalui pertumbuhan dunia usaha yang selama ini mengeluhkan panjangnya waktu dan rantai birokrasi yang harus dilewati untuk memulai suatu usaha.
Penerapan sistem perizinan berbasis elektronik merupakan harapan pemerintah sehingga perilaku birokrasi dalam pelayanan kepada masyarakat (pelaku usaha) mengandung sejumlah nilai tertentu yang memberikan ciri pekerjaan instansi pemerintah dalam melaksanakan tugasnya. Perilaku terkait dengan birokrasi dalam menjalankan tugasnya secara optimal berupa etos kerja birokrasi pemerintahan.

Menurut Ida Bagus Rahmadi Supancana (2006:1), produsen sering diartikan sebagai pengusaha yang menghasilkan barang dan jasa yaitu setiap orang/ badan yang ikut serta dalam penyediaan barang atau jasa hingga sampai ke tangan konsumen sedangkan pelaku usaha diartikan sebagai setiap orang perorangan atau badan usaha, baik yang berbentuk badan hukum maupun bukan badan hukum yang di dirikan dan berkedudukan atau melakukan kegiatan dalam wilayah hukum negara Republik Indonesia, baik sendiri maupun bersamabersama melalui perjanjian menyelenggarakan kegiatan usaha dalam berbagai bidang ekonomi."

Perilaku birokrasi dan pelaku usaha yang dapat mendukung tercapainya percepatan investasi melalui penerapan Online Single Submission (OSS)/ Sistem perizinan berusaha terintegrasi secara elektronik di Kabupaten Bangka Selatan.

Selanjutnya berdasarkan teori tersebut dan membedakan dengan penelitian sebelumnya yang hanya menggunakan 2 (dua) variabel maka penulis akan menggunakan tiga variabel yaitu X sebagai variabel independen yang terdiri dari perilaku birokrasi (X1) dan perilaku usaha (X2), Y sebagai variabel dependen yaitu Online Single Submission (OSS) dan Z sebagai variabel intervening yaitu percepatan investasi.

Selain itu juga alat analisis menjadi pembeda dengan studi terdahulu yaitu menggunakan Methode of Successive Interval (MSI) dengan software SPSS 2019 yang pada akhirnya penelitian ini bertujuan untuk 
1. Mengukur dan menganalisis seberapa besar pengaruh Online Single Submission (OSS)/ sistem perizinan berusaha terintegrasi secara elektronik terhadap perilaku birokrasi;

2. Mengukur dan menganalisis seberapa besar pengaruh penerapan Online Single Submission (OSS)/ sistem perizinan berusaha terintegrasi secara elektronik terhadap pelaku usaha;

3. Mengukur dan menganalisis seberapa besar pengaruh penerapan Online Single Submission (OSS)/ sistem perizinan berusaha terintegrasi secara elektronik terhadap perilaku birokrasi dan pelaku usaha serta dampaknya bagi percepatan investasi di Kabupaten Bangka Selatan Provinsi Kepulauan Bangka Belitung;

\section{METODE PENELITIAN}

Penelitian ini menggunakan metode penelitian kuantitatif yang dicirikan dengan pengumpulan data dan analasis data kuantitatif pada tahap pertama, dan diikuti dengan pengumpulan dan analisis data pada tahap ke dua, guna memperkuat hasil penelitian kuantitatif.

\section{HASIL DAN PEMBAHASAN}

Pada penelitian ini, peneliti akan melihat pengaruh 1 (satu) variabel dependent $(\mathrm{Y}$ ) terhadap 2 (dua) variabel independent $\left(\mathrm{X}_{1}\right.$ dan $\left.\mathrm{X}_{2}\right)$ serta dampaknya bagi 1(satu) variabel intervening (Z). Variabel dependent yaitu Online Single Submission (OSS)/ Sistem Perizinan Berusaha Berbasis Elektronik (Y) terhadap 2 (dua) variabel independent yaitu variabel perilaku birokrasi $\left(\mathrm{X}_{1}\right)$ dan variabel pelaku usaha $\left(\mathrm{X}_{2}\right)$ serta dampaknya bagi variabel intervening yaitu percepatan investasi (Z). Variabel Online Single Submission (OSS)/ Sistem Perizinan Berusaha Berbasis Elektronik $(\mathrm{Y})$, perilaku birokrasi $\left(\mathrm{X}_{1}\right)$, dan pelaku usaha $\left(\mathrm{X}_{2}\right)$ serta percepatan investasi (Z) akan dijabarkan kedalam sub variabelsub variabel serta indikator-indikator yang kemudian dirinci lagi dalam butir-butir pertanyaan atau pernyataan.

Berdasarkan sintesis dari teori-teori yang berhubungan dengan substansi penelitian, digambarkan pola hubungan antara variabel sesuai dengan tujuan penelitian, maka hubungan struktur atau pengaruh dari variabel penelitian yang digunakan dapat digambarkan seperti pada gambar dibawah ini.

Gambar 1

Pola Hubungan Variabel

Independent, Dependent, dan Intervening

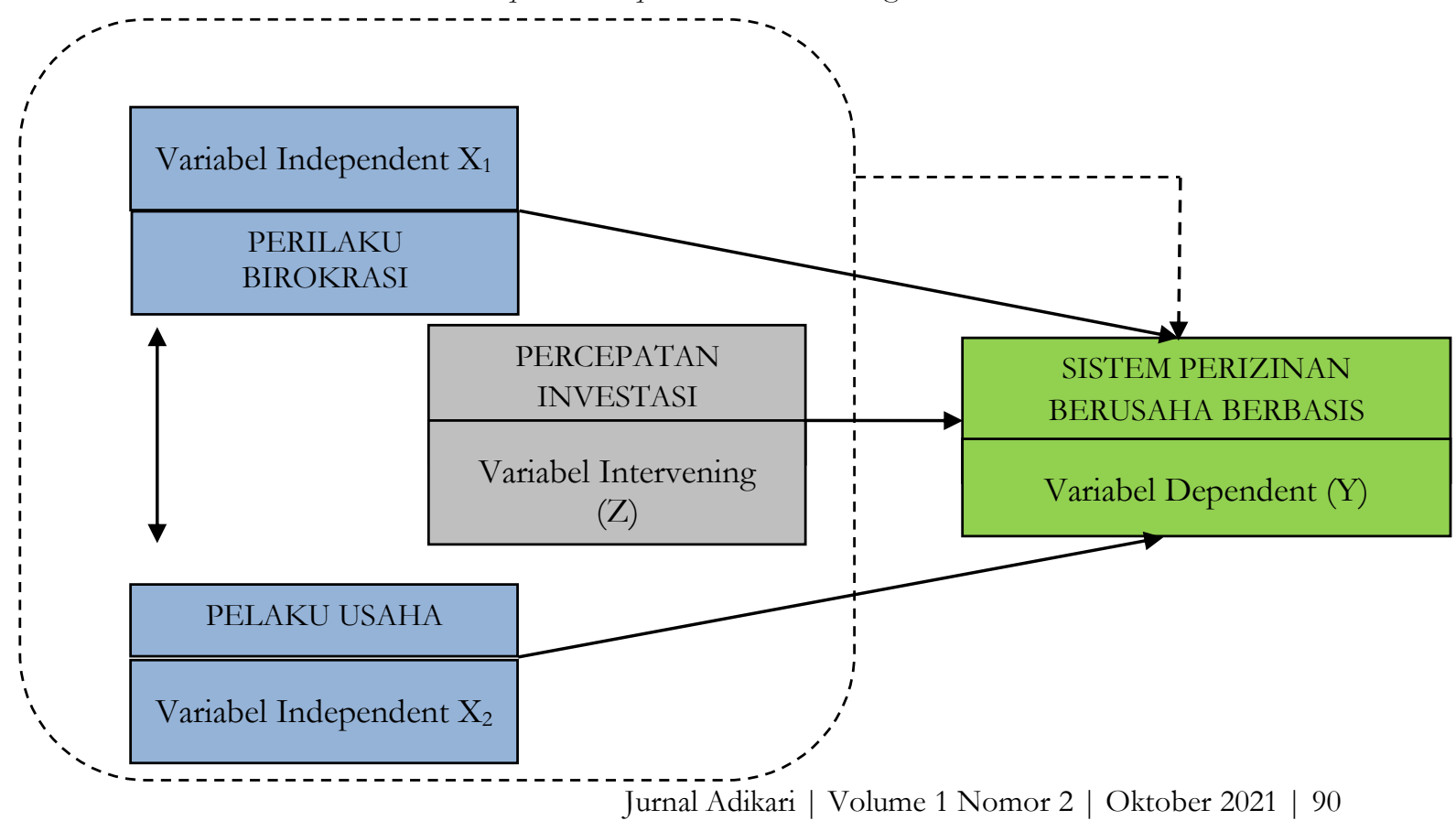


Variabel penelitian yang terdiri dari Online Single Submission (OSS)/ Sistem Perizinan Berusaha Berbasis Elektronik, Perilaku Birokrasi, pelaku usaha dan percepatan investasi perlu dirinci ke dalam instrumen masing-masing yang akan dijadikan bahan pengolahan dan pengujian data secara statistik. Adapun variabel yanng akan dibuat instrumennya berdasarkan objek penelitian ini yaitu menyangkut fenomena yang berkaitan dengan Online Single Submission (OSS)/ sistem perizinan berusaha berbasis elektronik, perilaku birokrasi, pelaku usaha, dan percepatan investasi.

Subjek penelitian Online Single Submission (OSS)/ sistem perizinan berusaha berbasis elektronik yakni penerapan sistem perizinan yang meliputi tahapan-tahapan Pendaftaran; Penerbitan Izin Usaha dan penerbitan Izin Komersial atau Operasional berdasarkan Komitmen; Pemenuhan Komitmen Izin Usaha dan pemenuhan Komitmen Izin Komersial atau Operasional; Pembayaran biaya; Fasilitasi; Masa berlaku; dan Pengawasan. Perilaku birokrasi adalah pejabat dan pegawai Pemerintah Daerah Kabupaten Bangka Selatan yang terkait dengan tugas pokok dan fungsinya pada bidang perizinan di lingkungan Pemerintah Daerah Kabupaten Bangka Selatan. Pelaku usaha terdiri dari pengusaha, grosir, leveransir, pengecer professional, orang dan atau badan usaha. Kemudian percepatan investasi yang memuhi asas-asas kepastian hukum, keterbukaan, akuntabilitas, perlakuan sama, kebersamaan, efisiensi berkeadilan, berkelanjutan, berwawasan lingkungan, kemandirian, dan keseimbangan kemajuan.

Ukuran sampel pada birokrasi Pemerintah Daerah Kabupaten Bangka Selatan yang didasarkan atas taraf kesalahan $5 \%$ atau kepercayaan $95 \%$ dari populasi yang berjumlah 300 orang, dapat ditentukan jumlah sampel yang representatif yaitu sebanyak 171 orang. Dengan demikian, maka jumlah sampel yang ditetapkan adalah sebanyak 57\% dari populasi. Sesuai dengan karakteristik populasi pertama yaitu birokrasi pada unit kerja terkait perilaku birokrasi yang berdampak pada percepatan investasi di Kabupaten Bangka Selatan yang terdiri dari strata jabatan atau eselon dan tersebar pada unit-unit kerja, maka teknik pengambilan sampel yang digunakan dalam penelitian ini adalah stratified random sampling.

Penelitian ini menggunakan pendekatan kuantitatif. Sedangkan instrumen yang merupakan bagian dari pendekatan kuantitatif dalam penelitian ini berupa kuisioner/angket yang disusun berdasarkan indikator dari masing-masing variabel terdiri dari pertanyaan/pertanyaan dengan jawaban pilihan ganda menurut skala likert. Analisis kuantitatif yang dilakukan didukung oleh analisis hubungan sebab akibat (causal relationship). Model yang dimaksud adalah hubungan antara variabel eksogen Online Single Submission (OSS)/ Sistem Perizinan Berusaha Terintegrasi Secara Elektronik (Y), Perilaku Birokrasi (X1) dan Pelaku Usaha (X2) sebagai variabel endogen serta Percepatan Investasi (Z) sebagai variabel intervening. Data ordinal disusun berdasarkan skala likert dengan menggunakan urutan rangking (skor) dari angka 1 sampai dengan angka 5. Kemudian data ordinal tersebut ditransformasikan secara sederhana menjadi data interval gunanya untuk memenuhi syarat analisis parametrik dengan menggunakan MSI (Methode of Successive Interval) (Riduwan dan Kuncoro, 2011:30).

Dari hasil penyebaran dan pengumpulan kembali kuesioner melalui google form kepada para responden sejumlah 171 orang terdiri laki-laki 117 orang atau $68,42 \%$ dan perempuan sebanyak 54orang atau $31,58 \%$ dengan proporsi terbesar responden pada jenis pekerjaan pegawai negeri sipil (PNS) berjumlah 61 orang atau $35,67 \%$. Hal ini menandakan bahwa responden memiliki kemampuan dalam menganalisa dan mengambil keputusan secara cepat, tepat dan cerdas. 
Berdasarkan hasil perhitungan analisis jalur struktur ditemukan informasi secara objektif sebagai berikut:

a. Pengaruh perilaku birokrasi (X1) yang secara langsung mempengaruhi Online Single Submission $($ OSS $(Y)$ sebesar $=0,1242=0,0153$ atau $1,53 \%$

b. Pengaruh pelaku usaha (X2) yang secara langsung mempengaruhi Online Single Submission $(\mathrm{OSS}(\mathrm{Y})$ sebesar $=(-$ $0,010) 2=0,0001$ atau $0,01 \%$

c. Pengaruh percepatan investasi (Z) yang secara langsung mempengaruhi Online Single Submission $(\operatorname{OSS}(\mathrm{Y})$ sebesar $=(0,420) 2=0,1764$ atau $17,64 \%$

d. Pengaruh perilaku birokrasi (X1), pelaku usaha (X2), dan percepatan investasi $(Z)$ secara simultan yang langsung mempengaruhi Online Single Submission $(\mathrm{OSS}(\mathrm{Y})$ sebesar $\mathrm{R}$ square $=$ $0,262=26,2 \%$

Selanjutnya berdasarkan hasil perhitungan analisis uji $\mathrm{F}$ diketahui bahwa secara simultan perilaku birokrasi (X1), pelaku usaha (X2), dan percepatan investasi $(Z)$ berpengaruh signifikan terhadap Online Single Submission (OSS)/Sistem Perizinan Berusaha Terintegrasi Secara Elektronik $(\mathrm{Y})$ sedangkan berdasarkan hasil perhitungan analisis uji $\mathrm{T}$ menunujukan bahwa variabel perilaku birokrasi (X1) secara parsial (sendiri-sendiri) tidak berpengaruh terhadap variabel Online Single Submission (OSS)/Sistem Perizinan Berusaha Terintegrasi Secara Elektronik (Y). Hal ini dikarenakan nilai atau bobot rerata pada variabel perilaku birokrasi (X1) dan pelaku usaha (X2) secara parsial tidak konsisten untuk mewakili atau menopang variabel Online Single Submission (OSS)/Sistem Perizinan Berusaha Terintegrasi Secara Elektronik (Y) namun ternyata percepatan investasi ( $Z$ ) merupakan variabel yang sangat berpengaruh terhadap Online Single Submission (OSS)/Sistem Perizinan Berusaha Terintegrasi Secara Elektronik (Y).

\section{KESIMPULAN}

Berdasarkan hasil perhitungan SPPS dengan menggunakan Methode of Successive Interval (MSI) diperoleh hasil bahwa:

a. Pengaruh perilaku birokrasi (X1) yang secara langsung mempengaruhi Online Single Submission (OSS)/ Sistem Perizinan Berusaha Terintegrasi Secara Elektronik (Y) sebesar = $0,1242=0,0153$ atau $1,53 \%$.

b. Pengaruh pelaku usaha (X2) yang secara langsung mempengaruhi Online Single Submission (OSS)/ Sistem Perizinan Berusaha Terintegrasi Secara Elektronik $(\mathrm{Y})$ sebesar $=(-$ $0,010) 2=0,0001$ atau $0,01 \%$.

c. Pengaruh percepatan investasi (Z) yang secara langsung mempengaruhi Online Single Submission (OSS)/ Sistem Perizinan Berusaha Terintegrasi Secara Elektronik $(\mathrm{Y})$ sebesar = $(0,420) 2=0,1764$ atau 17,64 \%

d. Pengaruh perilaku birokrasi (X1), pelaku usaha (X2), dan percepatan investasi (Z) secara simultan yang langsung mempengaruhi Online Single Submission (OSS)/ Sistem Perizinan Berusaha Terintegrasi Secara Elektronik (Y) sebesar R square $=0,262=26,2 \%$

Berdasarkan hasil analisis diatas maka dapat dirumuskan kebijakan strategis dalam penerapan Online Single Submission (OSS)/ Sistem Perizinan Berusaha Terintegrasi Secara Elektronik di Kabupaten Bangka Selatan, yaitu:

a. Mempermudah layanan Online Single Submission (OSS)/ Sistem Perizinan Berusaha Terintegrasi Secara Elektronik dengan mempersiapkan SDM yang profesional;

b. Peningkatan Kapasitas SDM yang ada di Kabupaten Bangka 
Selatan dalam rangka menghadapi Online Single Submission (OSS)/

Sistem Perizinan Berusaha Terintegrasi Secara Elektronik;

c. Melakukan edukasi dan monitoring serta evaluasi terhadap pelaksanaan Online Single Submission (OSS)/ Sistem Perizinan Berusaha Terintegrasi Secara Elektronik di Kabupaten Bangka Selatan;

d. Meningkatkan kontribusi dan percepatan investasi di Kabupaten Bangka Selatan.

\section{DAFTAR PUSTAKA}

Achmad Kuncoro, Engkos, dan Riduan. 2011. Cara Menggunakan dan Memakai Path Analysis. Bandung: CV Alfabeta

Bryson J.M Perencanaan Strategis bagi Organisasi Sosial (Strategic Planning for Public and Non ProfitOrganization : A guide Strengnthening and Suistainning Organizational Achievement) diterjemahkan oleh M. Miftahudin Cet. 9 (Yogyakarta: Pustaka Pelajar, 2008).

Dedi Rianto Rahadi, Peranan Teknologi Informasi dalam Peningkatan Pelayanan di Sekitar Publik, (Yogyakarta:Seminar Nasional Teknologi).

Ghozali, Imam. 2005. Aplikasi Analisis Multivariate dengan program SPSS, Badan Penerbit Universitas Diponegoro, Semarang.

Juanim, Analisis Jalur dalam Riset Pemasaran Teknik Pengolahan Data SPSS \& LISREL (Bandung: Fakultas Ekonomi Universitas Pasundan, 2004).

Lucas, Henry J. 2000. Information Technology For Management, Irwin/Mcgraw- Hill
Singarimbun, Masri \& Sofian Effendi. 2008. Metode Penelitian Survei, Jakarta: LP3ES.

Sugiyono. (2014). Metode Penelitian Pendidikan Pendekatan Kuantitatif, Kualitatif, dan R\&D. Bandung: Alfabeta.

Wahid, F. (2013) “Translating the Idea of the eGovernment One-Stop Shop in Indonesia", Proceedings of the Information \& Communication

Wahid, F. (2017). Pengembangan Sistem Informasi Pelayanan Terpadu Satu Pintu: Perspektif Action Design Research. Seminar Nasional Teknologi Informasi dan Bisnis. Surakarta: STMIK Duta Bangsa.Technology-EurAsia Conference 2013, Yogyakarta, Indonesia.

93 | Orywika, M. Faisal, et.all. Pengarub Penerapan Online Single Submission (OSS) terhadap Perilaku Birokrasi dan Pelaku Usaha serta Dampaknya bagi Percepatan Investasi Di Kabupaten Bangka Selatan Provinsi Kepulauan Bangka Belitung 